The Future of Monetary Policy:

The Rational Expectations Perspective (p.l)

A Case for Branch Banking in Montana (p. 8)

District Conditions (p. 18)

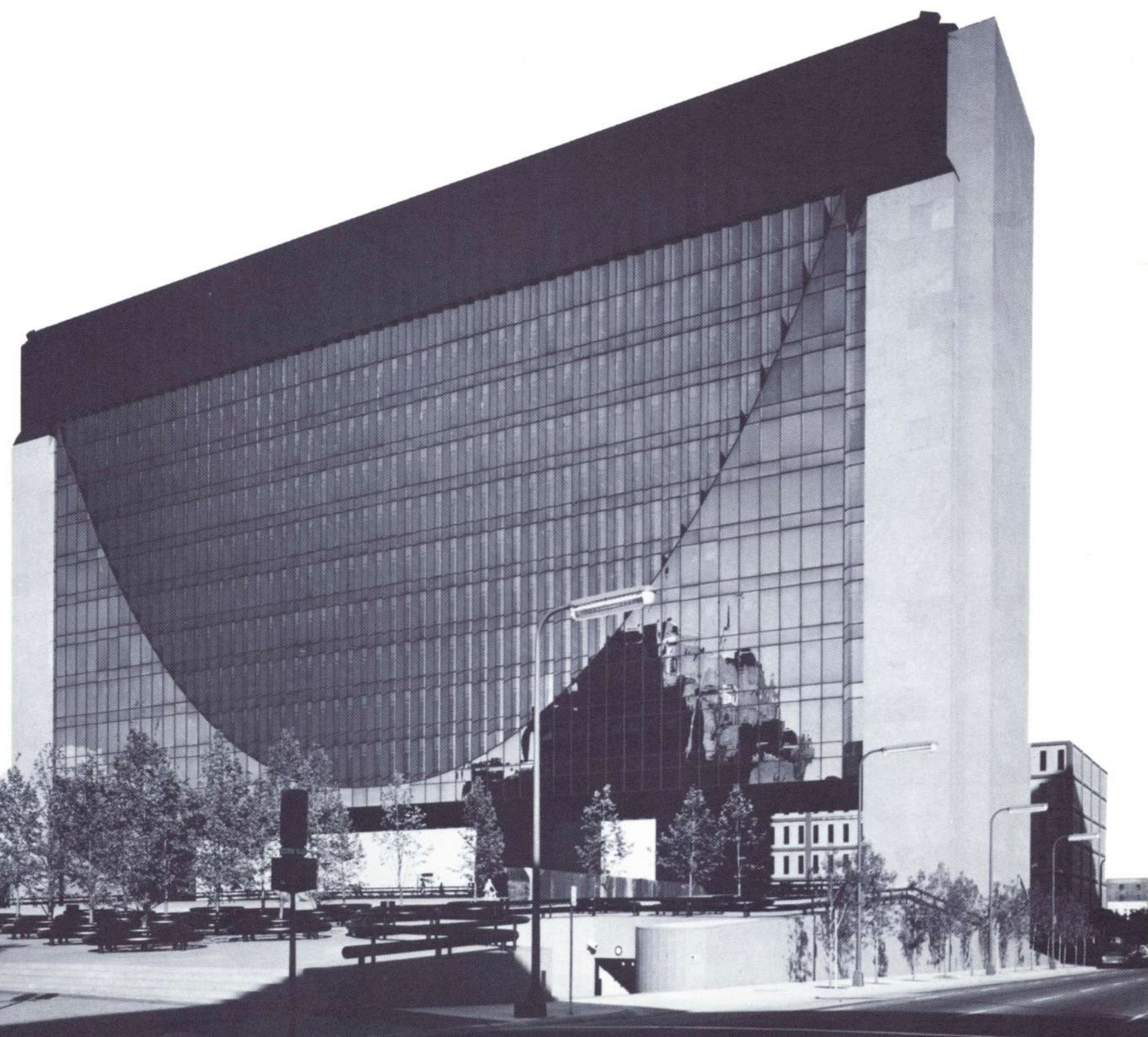


Federal Reserve Bank of Minneapolis Quarterly Review vol. 4, No. 2

This publication primarily presents economic research aimed at improving policymaking by the Federal Reserve System and other governmental authorities.

Produced in the Research Department. Edited by Arthur J. Rolnick, Kathleen S. Rolfe, and Alan Struthers, Jr. Graphic design by Phil Swenson and charts drawn by Mary K. Steffenhagen, Graphic Services Department.

Address requests for additional copies to the Research Department, Federal Reserve Bank, Minneapolis, Minnesota 55480.

Articles may be reprinted if the source is credited and the Research Department is provided with copies of reprints.

The views expressed herein are those of the authors and not necessarily those of the Federal Reserve Bank of Minneapolis or the Federal Reserve System. 


\section{A Case for Branch Banking in Montana*}

Stanley L. Graham, Economist

Arthur J. Rolnick, Assistant Vice President

Research Department

Federal Reserve Bank of Minneapolis

Since Adam Smith published The Wealth of Nations in 1776, economists have argued for fewer government restrictions on economic activities. Smith theorized that individuals pursuing their own interests in the marketplace are led - as if by an invisible hand - to achieve the most good for all; their profit-motivated behavior results in consumers getting the goods and services they want, produced at the lowest possible costs and offered to them at the lowest possible prices. Any government interference with this private competition is therefore almost certain to lead to inefficiencies and higher prices and can only be justified to enforce contracts or to prevent otherwise inevitable monopolistic practices. Following Smith, many economists have argued for free trade among countries, for unrestricted entry into all kinds of economic pursuits, and for a very limited role for government.

Yet while Adam Smith and his followers have made a strong theoretical case for freedom in the marketplace, they haven't often been able to find as convincing support for their case in the real world. Either data have simply not been available for the particular type of economic activity they're considering, or isolating the impact of a particular government restriction from the impacts of the many other influences on economic activity has been very difficult.

The case for allowing banks the freedom to branch is an exception. Restricting the type of offices banks can open, as Montana and other largely rural states do, is clearly a form of government intervention that Adam

*A report prepared for the Interim Committee on Branching of Financial Institutions, Montana State Legislature, April 1980.
Smith would have questioned. It prevents willing providers of a service from selling to willing customers and thus, according to him, does not achieve the most good for all-unless, of course, it truly is preventing some form of noncompetitive behavior. Whether or not that is so can, in this case, be evaluated by more than Smith's theory. A considerable amount of relevant empirical evidence is available: Many states have permitted some form of branch banking, and their experience has been analyzed extensively.

The evidence clearly supports allowing banks more freedom. It strongly suggests that many common concerns over the impact of branching on competition in the banking industry are unwarranted. Permitting branching does not drive small independent banks out of business or reduce the amount of credit rural communities can get or increase what they have to pay for it and other banking services. On the contrary, where branch banking has been allowed, large and small banking systems compete quite vigorously, and on average consumers in rural areas are offered more places to bank and a wider variety of banking services. While branching clearly changes some features of the banking market, it has not led to monopoly pricing, but rather to more banking services offered to more people at competitive prices.

The evidence, in short, shows that branch banking has had a positive influence wherever permitted, just as Adam Smith would have predicted. But will it have similar effects in Montana? Considering the current structure of financial institutions and markets in this state, we believe that it will. 


\section{Experience With Branch Banking in the United States}

Whether or not banks can branch in the United States has historically been a question left to each individual state to answer. Over the years the trend has been toward allowing some form of branching, but at any time in this century a significant number of states have completely prohibited it (see Chart 1).

Today 21 states and the District of Columbia permit branching anywhere within their borders and 16 states permit branching within limited areas - mostly within the bank's home office county and the counties surrounding it. This leaves 13 states that by law or practice still completely prohibit branching. Commonly referred to as unit banking states, these 13 states have a close geographic and economic relationship. All but 2 of them are located in the cluster of states between the Mississippi River and the Rocky Mountains, running from Montana, North Dakota, and Minnesota in the north to Texas in the south (Chart 2). And all of the unit banking states are largely rural and contain mostly small banking organizations.

\section{Fears about branching are unwarranted}

The opposition to branch banking in these states has mainly been based on fears that the ability to branch will reduce competition in the banking industry and so increase the cost and reduce the availability of banking services for rural consumers. Specifically, opponents fear that this will happen because they believe that

1. Branch banks siphon funds out of rural areas.

2. Branch banks are less efficient than unit banks.

3. Large branch banks drive small unit banks out of business.

4. Branching leads to increased bank concentration.

The experience with branch banking in the United States has allowed researchers to test the validity of these concerns. Comparing states that allow branching to those that don't, comparing branch banks to unit banks in the same state, and comparing banks before and after they become part of a branching system has provided fertile ground for economic analysis. The evidence from these studies is quite conclusive: all four fears about branching are unwarranted.

\section{Branch banks do not siphon funds out of rural areas}

One of the most emotional issues surrounding branching is the contention that branches are established mainly to gather deposits from rural towns in order to provide loans to the head office's large corporate customers. Since bank credit is essential to the economic development of rural communities, opponents argue, this siphoning will lead to depressed economic conditions in these communities.

Proponents of branching disagree that siphoning of funds out of rural areas is the inevitable result of branch banking. They argue that a bank with branch offices is likely, rather, to increase the amount of funds available in rural communities because its loan portfolio is more geographically dispersed and therefore less risky than that of a unit bank. Thus, it can hold

\section{Chart 1}

The Trend Toward Branch Banking in the United States

Number of States Prohibiting or Allowing Some Form of Branch Banking in the Last 50 Years

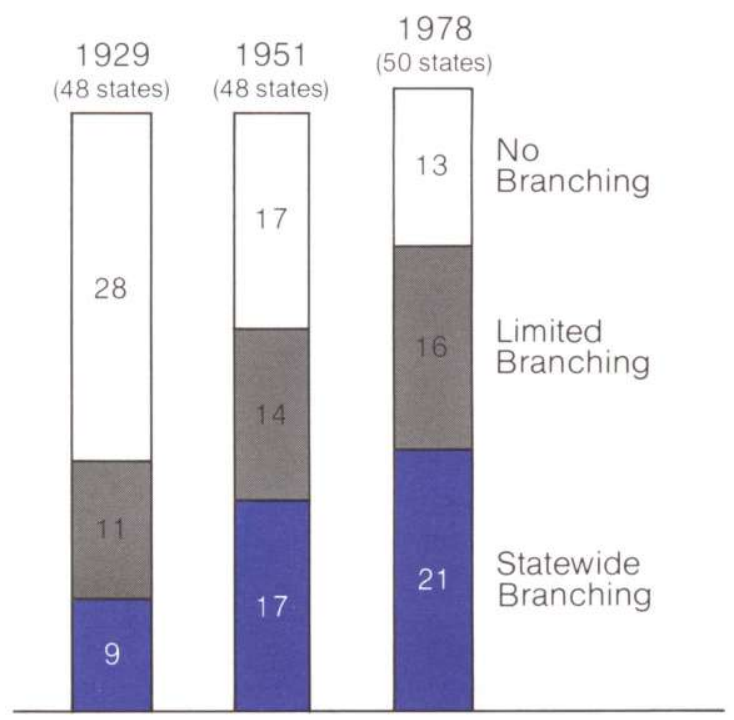

Sources: White 1976, American Bankers Association 


\section{Chart 2}

\section{Thirteen states still completely prohibit branch banking.}

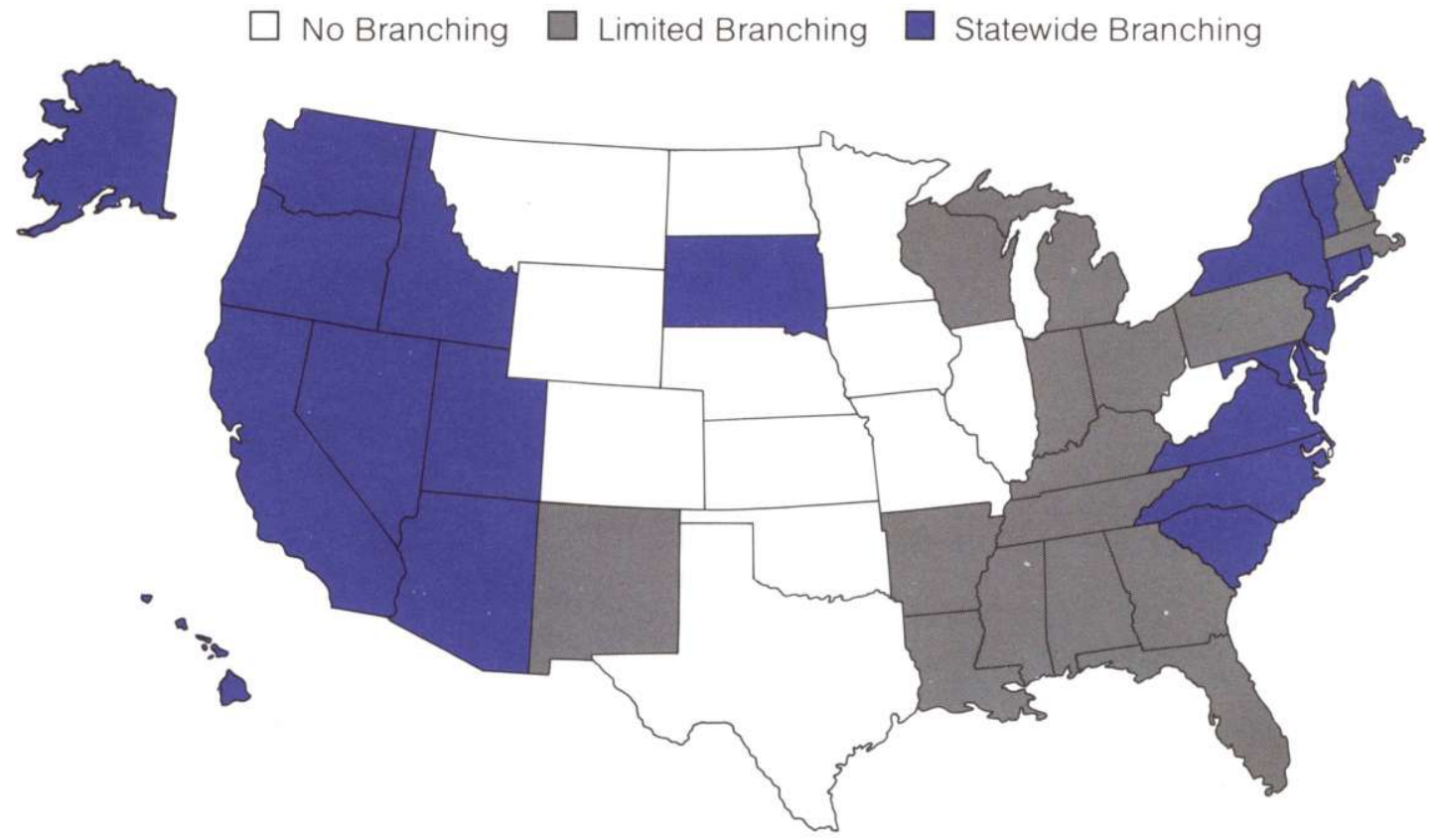

Source: American Bankers Association

more loans per dollar of deposit than a unit bank can.

Data explicitly revealing where bank borrowers are or where borrowers spend the proceeds of their loans are not available to settle this dispute conclusively. The indirect evidence on fund flows, however, does not support the siphoning hypothesis.

Studies comparing the share of funds loaned out at branch and unit banks suggest that, on average, branch banks loan more of their funds in the communities in which they are located. For example, Schweiger and McGee (1961), examining all member banks by deposit size in 1959, found that branch banks had higher loan-to-deposit ratios than unit banks in both urban and rural areas. And Horvitz and Shull (1964), analyzing 3,000 member banks in 1962 and 1963, found that branch banks had higher loan-to-asset ratios than unit banks located in states that either prohibited or allowed branching. This is not unquestionable evidence that branch banks loan more funds to rural communities, however. The higher ratios may simply represent funds siphoned to the home office's large corporate customers, as opponents of branching fear.

When all home office data are excluded from the calculations, though, the flow of funds evidence still does not support the siphoning argument. Two studies of banking in New York State (Kohn 1964 and Kohn, Carlo, and Kaye 1973) concluded that on balance there was no significant statistical difference between the loan-to-deposit ratios of out-of-town branch offices and those of unit banks. Johnston's (1967) study of California banks did find a difference-in favor of branch banks: calculated without data from the home office, their loan-to-deposit ratios remained higher than unit banks'. Consistent with this is Kohn's (1964) finding that loan portfolios of most unit banks increased after they became branches. 


\section{Branch banks are not less efficient}

Opponents of branch banking also argue that branch banks are less efficient than unit banks. They contend that the extra costs inherent in overseeing a large branch network more than offset any advantage branch banks may have from centralizing certain bank operations such as personnel management, purchasing, and investment portfolio management. And branch banks probably pass some of that extra cost on to consumers in the form of higher prices for their services.

Early studies supported this position. Three different studies of bank efficiency concluded that unit banks were more efficient than branch banks: Alhadeff (1954), analyzing California banks; Schweiger and McGee (1961), analyzing members of the Federal Reserve System; and Horvitz (1963), analyzing all insured commercial banks. All three studies based their conclusion on the finding that expense-to-asset ratios were higher for branch banks than for unit banks of the same asset size.

These studies, however, suffer from two serious methodological problems - problems largely created by lack of data - which bring their common conclusion into question. One problem is the assumption that bank output can be adequately represented by just one number, total assets. This assumption ignores the fact that banks produce many goods (various types of loan, deposit, and trust services, for example) and that the mix of goods may differ for any two banks with identical total assets. The other problem with these studies is that simply comparing branch and unit banks of the same size fails to recognize the added service that multiple locations provide customers of branch banks. To customers the total cost of doing banking business includes not only what they have to pay the banking office directly for their services, but also the time, trouble, and transportation expense involved in getting them.

These methodological problems have been substantially reduced in more recent studies. Using a newly available body of data, researchers have constructed measures of costs based on a variety of bank services to replace the single ratio of earlier studies. And to account for the difference in customer convenience between single-office unit banks and multipleoffice branch banks, researchers have compared a branch bank, not with a unit bank of the same size, but with a collection of unit banks of the same size as the branch bank's individual offices.
Using these more extensive data, studies of the efficiency controversy come to quite different conclusions than the earlier studies. Mullineaux (1973), studying commercial banking in the Boston, New York, and Philadelphia Federal Reserve Districts, and Longbrake (1973), studying a wide sample of unit and branch banks, concluded that there were no systematic differences in efficiency between branch and unit banks. Benston (1965) and Bell and Murphy (1968) actually reversed the earlier results. They concluded that branch banks were more efficient than unit banks: although the costs of adding branches appeared to offset the savings from increased size, branch banks were able to provide more services in the form of a larger number of offices.

\section{Large branch banks do not drive small unit banks out of business}

Small firms of all kinds-including banks-have traditionally feared that a large firm with a large stock of capital can drive them out of business by temporarily pricing its goods and services below cost. The hypothesis is that a large firm foregoes normal profits in the short run by pricing below cost with the expectation that in the long run it will be able to charge monopoly prices and obtain above-normal profits. This hypothesis requires that entry costs to a market be high enough so that the large firm is eventually able to recoup its losses from the initial price cutting before other firms, drawn by the chance for "above-normal" profits, enter the market and compete the price back down

The banking industry, however, does not appear to meet this requirement. The amount of capital necessary to establish a branch office is very low, so that large branch banks are not likely to price below cost in order to drive their competitors out of business; they simply would not be able to recoup their losses. A study of the effects of New York City banks branching for the first time in neighboring Westchester and Nassau Counties in 1960-64 supports this judgement. Kohn and Carlo (1969) found that the opening of branches in these counties did not significantly reduce the profitability of unit banks already there. Furthermore, simple observation bears this out. Unit banks have competed side by side with branch banks for over 50 years in many states, including Vermont, California, and the Carolinas.

Of course, it would not be realistic to assume that 
every unit bank would survive competition from any new bank, whether a branch office or another unit bank. The continued health of the financial system as well as of the economic system generally depends on the constant pruning of inefficient firms.

\section{Branching may increase concentration but not decrease competition}

Perhaps the oldest and most vocal argument against branch banking is that permitting it will lead to increased concentration, that is, to significantly fewer firms controlling much larger shares of the market for banking services. Although seldom spelled out, an inincrease in concentration implies a decrease in competition which results in higher prices and fewer banking services.

But concentration in the banking industry has never been well defined, so that no definite link between it and branching has been isolated. Even if it had been, though, there would still be a link missing: increases in the concentration of firms and the prices and services they offer consumers have not been clearly connected either by economic theory generally or by empirical studies of the banking industry.

Concentration generally refers to the proportion of an industry's sales or assets which is made or held by the largest firms in the market for the industry's goods or services. An adequate measure of concentration, therefore, requires identification of both the market and the competitors in that market.

The measure of concentration of banking services that opponents of branching typically use is the percentage of bank deposits in the state held by the largest banks. Anyone using this ratio as a measure of concentration obviously assumes that the state is the relevant market for banking services and banks are the competitors in that market.

This assumption, however, is highly questionable. Banks offer a large number of services to a diversified set of consumers, and it is much more likely that there are a number of markets of differing geographic dimensions. The nation may be the relevant market for some services and bank customers (large business loans, for example). The local community may be the relevant market for others (like individual checking accounts and consumer loans). Moreover, for certain types of services, banks compete with many other financial institutions (for example, with savings and loan associations and credit unions for time deposits).
Given the difficulties in defining the appropriate concepts behind a measure of concentration, it should not be surprising that the evidence on whether or not branching increases concentration is mixed.

Measured by shares of deposits held by the largest urban banks, concentration seems to increase in states and in metropolitan areas when statewide branching is introduced. Statewide branching states currently have higher concentration ratios than unit banking states. In 1978 , the average ratio (based on the five largest banks in each area) was 73 percent in statewide branching states and only 37 percent in unit banking states. In the urban areas of these states, the corresponding ratios were 81 and 61 percent. In addition, over the past 25 years, concentration ratios have decreased in unit banking states while they have increased in statewide branching states and in states that have liberalized their branching laws.

When branching is introduced to rural areas, however, concentration seems to decrease. Ratios are not available based on deposits held by the largest banks for rural banking markets, but here the number of banking offices is a good proxy. Rural banks are not likely to branch in their own small local markets, so an increase in the number of offices in these areas can safely be assumed to represent an increase in the number of competing firms and thus a decrease in the concentration of banking services there. And that's what appears to happen when banks can branch. Horvitz and Shull (1964) found that, when other factors such as population density are taken into account, the average number of commercial bank offices in U.S. nonmetro areas is larger where statewide branching is allowed.

Whether or not higher concentration actually leads to higher prices and fewer services is similarly ambiguous. The relationship between concentration and prices and services does not have a strong theoretical grounding. Economic theory tells us what is likely to happen when barriers to entry limit the market to one firm (monopoly) rather than many firms (perfect competition). The monopoly produces less than the competitive firms and charges a higher price. But theory does not say how many firms are necessary for competition or what the effect on competition is likely to be from changes in the relative size of firms in the market.

The empirical evidence doesn't answer these questions either. Using the bank deposit measure again, 
many studies have examined the relationship between changes in concentration for a particular area and the price of a particular banking service.

Edwards (1964, 1965), Flechsig (1965), Jacobs (1971), and Phillips (1967) studied interest rates on business loans, and their results were inconclusive. Flechsig found no statistically significant relationship between these interest rates and concentration, while the others all found a weak, positive relationship. Jacobs, for example, examined the determinants of the rates charged on loans to 8,000 customers at 160 banks in metropolitan areas across the country. Accounting for the deposits held by borrowers, the size and collateral of loans, and other factors, he found a statistically significant relationship between concentration and interest rates on business loans. But the impact he found was small: as large as a 10 percent increase in concentration yielded only a 5 basis point increase in interest rates.

Studies of concentration and rates on bank deposit accounts reached somewhat similar conclusions. Service charges on demand deposits and interest rates on time deposits were examined by Bell and Murphy (1968) and Edwards (1965), respectively. Again, the relationships to concentration were statistically significant but quantitatively small.

On the supposition that these studies, by focusing on one price, might have underestimated the impact of concentration in the banking industry, Heggestad and Mingo (1976) examined the price and availability of a spectrum of bank services, including interest rates on time deposits and new car loans, monthly charges on checking accounts, availability of overdraft services, and the total number of hours the bank was open each week. Their supposition seems to have been wrong. Where they found a statistically significant relationship to concentration, they too found only a small quantitative impact. And that was only for about half the services they examined. For the other half, they found no significant relationship at all.

\section{Branching benefits consumers}

The available data thus do not support the traditional fears about branching: the results of nationwide studies let us conclude that relaxing prohibitions against branching will not make consumers pay more for fewer banking services. But as Adam Smith would, we can now go further: Freeing banks from restrictions on branching not only will not hurt consumers, it will actually benefit them.

\section{- Branching provides more banking offices}

For metropolitan areas, the evidence is clear that branch banking results in more offices being available to consumers of banking services. Table 1 shows that in 1974 there were about twice as many banking offices in standard metropolitan statistical areas (SMSAs) of statewide and limited branching states as in those of unit banking states. This advantage holds regardless of the size of the SMSA.

The difference in the number of banking offices between branching and unit banking SMSAs can be confidently attributed to differences in bank branching laws. If these legal differences were not significant, we would expect nonbank financial firms to also have about twice as many offices in branching SMSAs as in unit banking SMSAs, but that is not true. Since the late 1960s, federal savings and loan associations (S\&Ls) have been permitted to branch within any state, and as

\section{Table 1}

The freedom to branch gives consumers more places to bank.

Average Number of Financial Offices in U.S. Metropolitan Areas in the 1970s

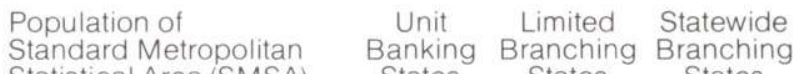

Statistical Area (SMSA) States States States

Bank Offices (1974)

$\begin{array}{llll}50,000-99,999 & 10 & 16 & 20\end{array}$

$\begin{array}{llll}100,000-499,999 & 24 & 47 & 54\end{array}$

$\begin{array}{llll}500,000-999,999 & 67 & 131 & 145\end{array}$

$1,000,000$ and over $\quad 211 \quad 452 \quad 338$

$\begin{array}{llll}\text { All SMSAs } & 49 & 110 & 112\end{array}$

Savings and Loan Offices (1970)

$\begin{array}{llll}\text { All SMSAs } & 19 & 25 & 25\end{array}$

Sources: Federal Deposit Insurance Corporation, Federal Home Loan Bank Board 
Table 1 shows, there are only slightly more S\&L offices in bank branching SMSAs than in unit banking SMSAs.

That branching provides more banking offices is also clear for nonmetropolitan areas. As noted earlier, Horvitz and Shull (1964) found that when factors such as population density are considered, on average, statewide branching states have more banking offices per rural town than do unit banking states. They found this to be true for nine out of ten population sizes.

Even stronger evidence that branching results in more banking offices comes from the experience in states which have relaxed their branching laws. One recent example is Minnesota, a unit banking state, which in 1977 permitted each bank to open two detached facilities within 25 miles of the bank as long as they were not placed in small communities already served by banks; in other words, small community banks were given home office protection. In the first $2 \frac{1}{2}$ years the new law was in effect, 137 detached facilities opened in Minnesota, thereby increasing the number of bank offices in the state 18 percent. And the bulk of these new offices were not located in metropolitan areas, as one might expect given the home office protection clause. Instead, 44 percent of the new offices were in rural Minnesota towns, and 22 percent of them were in communities which previously had no banking offices.

\section{- Branching provides a wider range of banking services}

The evidence suggests that branching also results in consumers being offered a wider range of banking services. Weintraub and Jessup (1964) studied this question nationally for a number of banking services, including revolving credit, trust services, special checking accounts, payroll services, and foreign exchange services. As might be expected, they found that about the same percentage of large branch banks and large unit banks offered these services and that more large branch banks offered them than did small unit banks. But they also found that for banks with less than \$25 million in deposits, being allowed to branch did make a difference: the services were offered by a bigger share of the branch banks than the unit banks. Kohn (1964) made a similar study in New York State for selected banking services and reached a similar conclusion: regardless of size, more branch banks than unit banks made the services available.

\section{What the U.S. Experience Means for Montana}

Is this evidence on the merits of branch banking applicable to the unit banking state of Montana? Based on the current structure of financial institutions and markets in Montana, we think so.

\section{An Underbanked State}

The number of banks and the number of people in Montana strongly suggest that the state has an unmet demand for banking services. Allowing banks to branch, then, would likely benefit consumers in Montana just as it has those in other states.

For its current population size, Montana has a relatively small number of banking offices. Its two SMSAs - Billings and Great Falls - had 11 and 9 banks, respectively, in June 1978. Compared to other SMSAs with the same population size $(50,000$ to $100,000)$, this number of banks is about the same as for SMSAs in other unit banking states, but only half as large as for SMSAs in statewide branching states (Table 1). Rural areas of Montana have the same disadvantage. Compared to South Dakota - a branching state that shares Montana's extremely low population density - Montana has fewer banking offices per town for seven out of nine population categories (Table 2).

\section{An Unnecessary Concern}

Many have argued that branching would not benefit consumers in Montana because the state has a high concentration of bank deposits in two multibank holding companies. As of June 1979, First Bank System and Northwest Bancorporation together had 22 bank affiliates which altogether held 38 percent of all the deposits in the state. The concern of many people, of course, is that if branching were allowed, these two organizations, starting with an already high level of concentration, would grow and reduce competition substantially more.

Some growth by these organizations might be expected if Montana allowed branching, given the evidence we have seen. And any potential decrease in bank competition is a proper matter for concern. However, we have argued that concentration is difficult to 
measure adequately, and alone it is not necessarily a good indication of the degree of competition in banking. Moreover, Montana has three features which minimize our concern about its banking industry.

First, Montana has a third large banking organization: Western Bancorporation. Although today it holds less than 5 percent of bank deposits in the state, it represents a potential major competitor for First Bank System and Northwest Bancorporation.

Second, even if the state had no third large firm, Montana's two-banking firm concentration ratio is not high compared to other states'. In 1978, the ratios of 17 other states were higher.

Third, evidence suggests that even a very high twobank concentration ratio does not raise banking prices or reduce banking services. In 1977 Dahl, Graham, and Rolnick examined the prices and services in

\section{Table 2}

Consumers of banking services in Montana are at a disadvantage.

Average Number of Bank Offices in Montana and South Dakota

Nonmetropolitan Communities in $1978-79^{*}$

\begin{tabular}{|c|c|c|}
\hline $\begin{array}{l}\text { Population } \\
\text { of Community }\end{array}$ & $\begin{array}{c}\text { Montana } \\
\text { (Unit Banking) }\end{array}$ & $\begin{array}{c}\text { South Dakota } \\
\text { (Statewide Branching) }\end{array}$ \\
\hline Less than 500 & .29 & .51 \\
\hline $500-999$ & .73 & 1.07 \\
\hline $1,000-1,999$ & .93 & 1.26 \\
\hline $2,000-2,999$ & 1.90 & 1.63 \\
\hline $3,000-4,999$ & 1.82 & 1.67 \\
\hline $5,000-7,499$ & 1.40 & 1.67 \\
\hline $7,500-9,999$ & 1.25 & 4.00 \\
\hline $10,000-14,999$ & 3.50 & 5.80 \\
\hline $15,000-24,999$ & 4.33 & - \\
\hline 25,000 and over & 6.00 & 7.00 \\
\hline \multicolumn{3}{|c|}{$\begin{array}{l}\text { * Size of town is based on } 1970 \text { census. Number of bank } \\
\text { offices is as of June } 30,1978 \text {, for banks and December } 31 \text {, } \\
1979 \text {, for branches. }\end{array}$} \\
\hline \multicolumn{3}{|c|}{$\begin{array}{l}\text { Sources: U.S. Department of Commerce, Bureau of the } \\
\text { Census; Federal Reserve Bank of Minneapolis; } \\
\text { Federal Deposit Insurance Corporation }\end{array}$} \\
\hline
\end{tabular}

Minnesota, a state whose 48 percent two-bank concentration ratio exceeds Montana's by a full 10 percentage points. The study found that, compared to urban banks in more restrictive states, banks in MinneapolisSt. Paul charged higher prices for some services and lower prices for others, and they generally provided more services (Table 3). Few of the differences were statistically significant, but those that were indicated that bank competition was keener in Minnesota.

\section{Conclusion}

Given the evidence on the impact of branch banking

Table 3

\section{Minnesota's high two-bank concentration ratio has not meant higher prices and fewer services.}
Prices and Services at Banks in Minneapolis-St. Paul and in SMSAs of States Which Prohibit Branching and Multibank Holding Companies †

\section{Based on 1973 survey by the Board of Governors of the Federal Reserve System}

\begin{tabular}{|c|c|c|}
\hline \multirow[b]{2}{*}{ Prices (averages of prices reported) } & $\begin{array}{l}\text { Minneapolis- } \\
\text { St.Paul } \\
\text { Banks }\end{array}$ & $\begin{array}{c}\text { Urban Bank } \\
\text { in More } \\
\text { Restrictive } \\
\text { States }\end{array}$ \\
\hline & & \\
\hline $\begin{array}{l}\text { Interest Rates on: } \\
\text { Savings deposits } \\
\text { Auto installment loans }\end{array}$ & $\begin{array}{l}4.59 \% \\
9.49\end{array}$ & $\begin{array}{l}4.52 \% \\
9.36\end{array}$ \\
\hline $\begin{array}{l}\text { Services Charges for: } \\
\text { Checking accounts (monthly) } \\
\text { Nonsufficient funds checks (unit) } \\
\text { Safety deposit boxes (min. annual) }\end{array}$ & $\begin{array}{r}\$ .28 \\
3.30 \\
5.60\end{array}$ & $\begin{array}{r}\$ 1.02 \\
2.49 \\
5.18\end{array}$ \\
\hline \multicolumn{3}{|l|}{ Services } \\
\hline $\begin{array}{l}\text { Availability (\% of banks offering) } \\
\text { Overdraft credit } \\
\text { Automated } 24 \text {-hour service } \\
\text { Conventional mortgages } \\
\text { Trust services }\end{array}$ & $\begin{array}{l}100 \% \\
20 \\
100 \\
20\end{array}$ & $\begin{array}{l}36 \% \star \\
18 \\
91 \\
55\end{array}$ \\
\hline Hours Open Weekly (averages) & 40.6 & $34.9 \star$ \\
\hline Number of banks in survey & 5 & 22 \\
\hline \multicolumn{3}{|c|}{$\begin{array}{l}\text { t Illinois, Kansas, Nebraska, Oklahoma, and West Virginia; SMSAs are } \\
\text { standard metropolitan statistical areas. }\end{array}$} \\
\hline \multicolumn{3}{|c|}{$\star$ Difference is significant at $10 \%$ level. } \\
\hline Source: Dahl, Graham, and Rolnick 1977 & & \\
\hline
\end{tabular}


throughout most of the United States, and given the structure of banking in Montana, we conclude that allowing Montana banks the freedom to branch would be a boon to the customers they serve. We would expect the change to bring more offices and more conveniently located offices. We would also expect a wider variety of bank services to be offered throughout the state and especially in rural areas.

\section{References}

Administrator of National Banks. 1966. Studies in banking competition and the banking structure: articles reprinted from The National Banking Review. Washington, D.C.: U.S. Treasury.

Alhadeff, David A. 1954. Monopoly and competition in banking. Berkeley: University of California Press.

Bell, Frederick W., and Murphy, Neil B. 1968. Costs in commercial banking: a quantitative analysis of bank behavior and its relation to bank regulation. Research Report 41. Federal Reserve Bank of Boston.

Benston, George J. 1965. Branch banking and economies of scale. The Journal of Finance 20 (May): 312-31.

1973. The optimal banking structure: theory and evidence Journal of Bank Research 3 (Winter): 220-37. Also in Compendium of issues relating to branching by financial institutions, pp. 455-73. Prepared by the Subcommittee on Financial Institutions, U.S. Senate Committee on Banking, Housing, and Urban Affairs, 94th Cong., 2d sess., October 1976. Washington. D.C.

Dahl, David S.: Graham, Stanley L.; and Rolnick, Arthur J. 1977. Looking for evidence of noncompetitive behavior in Minnesota's banking industry. Federal Reserve Bank of Minneapolis Quarterly Review 1 (Fall): 1-7.

Edwards, Franklin R. 1964. Concentration and competition in commercial banking: a statistical study. Research Report 26. Federal Reserve Bank of Boston.

1965. The banking competition controversy. The National Banking Review 3 (September): 1-34. Also in Studies in banking competition and the banking structure: articles reprinted from The National Banking Review, pp. 303-36. Administrator of National Banks, 1966. Washington, D.C.: U.S. Treasury.

Flechsig, T. G. 1965. Banking market structure and performance in metropolitan areas. Washington, D.C.: Board of Governors of the Federal Reserve System.

Gilbert, Gary G., and Longbrake, William A. 1973, 1974. The effects of branching by financial institutions on competition, productive efficiency and stability: an examination of the evidence. Journal of Bank Research 4 (Autumn 1973): 154-67 (part 1), 4 (Winter 1974): 298-307 (part 2). Also in Compendium of issues relating to branching by financial institutions, pp, 475-98. Prepared by the Subcommittee on Financial Institutions, U.S. Senate Committee on Banking, Housing, and Urban Affairs, 94th Cong., 2d sess., October 1976. Washington, D.C.

Guttentag, Jack M., and Herman, Edward S. 1967. Banking structure and performance. The Bulletin 41/43 (February). New York University Graduate School of Business Administration, Institute of Finance.

Heggestad, Arnold A., and Mingo, John J. 1976. Prices, nonprices, and concentration in commercial banking. Journal of Money, Credit and Banking 8 (February): 107-17.

Horvitz, Paul M. 1963. Economies of scale in banking. In Private financial institutions: a series of research papers prepared for the Commission on Money and Credit, pp. 1-54. Englewood Cliffs, NJ: Prentice-Hall.

Horvitz, Paul M., and Shull, Bernard. 1964. The impact of branch banking on bank performance. The National Banking Review 2 (December): 143-88. Also in Studies in banking competition and the banking structure: articles reprinted from The National Banking Review, pp. 141-86. Administrator of National Banks, 1966. Washington, D.C.: U.S. Treasury.

Jacobs, Donald P. 1971. Business loan costs and bank market structure: an empirical estimate of their relations. Occasional Paper 115. National Bureau of Economic Research. 
Johnston, Verle. 1967. Comparative performance of unit and branch banks. In Bank structure and competition: a summary of discussion and selected papers presented at a conference, pp. 13-14. Chicago: Federal Reserve Bank of Chicago.

Kohn, Ernest. 1964. Branch banking, bank mergers, and the public interest. New York: New York State Banking Department.

Kohn, Ernest, and Carlo, Carmen J. 1969. The competitive impact of new branches. New York: New York State Banking Department.

Kohn, Ernest; Carlo, Carmen J.; and Kaye, Bernard. 1973. Meeting local credit needs. New York: New York State Banking Department.

Longbrake, William A. 1973. Productive efficiency in commercial banking: the impact of legal form of organization and size. Washington, D.C.: Federal Deposit Insurance Corporation.

Mote, Larry R. 1974. The perennial issue: branch banking. Business Conditions (February): 3-23. Federal Reserve Bank of Chicago. Also in Compendium of issues relating to branching by financial institutions, pp. 437-54. Prepared by the Subcommittee on Financial Institutions, U.S. Senate Committee on Banking, Housing, and Urban Affairs, 94th Cong., 2d sess., October 1976. Washington, D.C.

Mullineaux, Donald J. 1973. Branch versus unit banking: an analysis of relative costs. In Changing Pennsylvania's branching laws: an economic analysis/Technical Papers, pp. 171-227. Philadelphia: Federal Reserve Bank of Philadelphia.

Pakonen, R. Rodney. 1970. Branch regulation and its effect on commercial bank entry. Research Department Staff Report 3. Federal Reserve Bank of Minneapolis.

Phillips, Almarin. 1967. Evidence of concentration in banking markets and interest rates. Federal Reserve Bulletin 53 (June): 916-26.

Schweiger, Irving, and McGee, John S. 1961. Chicago banking. The Journal of Business 34 (July): 203-366.

U.S. Congress. Senate. Subcommittee on Financial Institutions, Committee on Banking, Housing, and Urban Affairs. 1976. Compendium of issues relating to branching by financial institutions. 94th Cong., $2 \mathrm{~d}$ sess., October. Washington, D.C.

Weintraub, Robert, and Jessup, Paul. 1964. A study of selected banking services by bank size, structure, and location. Prepared for the Subcommittee on Domestic Finance, U.S. House Committee on Banking and Currency, 88 th Cong., $2 \mathrm{~d}$ sess., November. Washington, D.C.

White, Roger S. 1976. The evolution of state policies on multi-office banking from the 1930's to the present. In Compendium of issues relating to branching by financial institutions, pp. 43-81. Prepared by the Subcommittee on Financial Institutions, U.S. Senate Committee on Banking, Housing, and Urban Affairs, 94th Cong., 2d sess., October. Washington, D.C.

Zorn. Robert E. 1980. The time is past for unit banking: the Texas experience. The Bankers Magazine 163 (January-February): 66-74. 